Abdurakhmonov Eldor, Junior researcher, Laboratory of Elemental Analysis of Institute of General and Inorganic Chemistry of Uzbekistan Academy of Sciences E-mail: eldor8501@mail.ru

Rakhmatkariev Gairat, Dr in chemistry, Prof., Head of Laboratory of Elemental Analysis of Institute of General and Inorganic Chemistry of Uzbekistan Academy of Sciences;

Rakhmatkarieva Feruza, Ph D., Researcher, Head of Laboratory of Elemental Analysis of Institute of General and Inorganic Chemistry of Uzbekistan Academy of Sciences Ergashev Oybek,

Ph D., Teacher, Namangan Engineering-Technological Institute Ministry of the higher and secondary special education of the republic of Uzbekistan

\title{
ADSORPTION-MICROCALORIMETRIC INVESTIGATION OF BENZENE CONDITION AND DISTRIBUTION IN THE ZEOLITE LIY
}

Abstract: Differential heats, isotherms, the differential entropies and thermokinetics of benzene adsorption in the zeolite LiY at $303 \mathrm{~K}$ have been measured using the method of adsorption calorimetry. Differential molar entropy and free energy of adsorption were calculated. The isotherms of adsorption were quantitatively reproduced on the basis of three-term VOM theory. These data formed the basis for identifying the detaled mechanism of benzene adsorption in LiY zeolite.

Keywords: Ion-molecular complexes, LiY zeolite, benzene, differential heats, isotherms, the differential entropies, thermokinetics, adsorption calorimetry.

\section{Introduction}

Zeolite [1] is microporous crystals possessing wide application in chemical and petrochemical industries as catalysts and sorbates $[2 ; 3]$. Method of adsorptive calorimetry is widely used in our practice ensuring detailed researches host-guest interaction in the systems adsorbent-adsorbate in wide space equilibrium pressure. The results these studies were confirmed such complementary methods as powder X-ray diffraction, NMR spectroscopy and computer modeling [4]. Before benzene adsorption was mainly studied in $\mathrm{Na}$ form zeolites type $\mathrm{X}$ and $\mathrm{Y}[5-7]$. We were set a goal to reveal detailed mechanism of benzene adsorption in the zeolite LiY based on results energy investigations.

Objective: to study isotherms and main thermodynamic characteristics of adsorption and the mechanism of adsorption of benzene in zeolite of $Y$ type with exchangeable $\mathrm{Li}^{+}$cations.

Subjects and Methods. Adsorption studies were carried out with zeolite Li Y. As adsorptives of benzene molecule were selected. Adsorption-calorimetric method used in this paper provides a highprecision molar thermodynamic characteristics of adsorption systems and through them to reveal the mechanism of adsorption processes occurring in the adsorbent. As a calorimeter the microcalorimeter Tian-Calvet-type, with high accuracy and stability was used $[11 ; 12]$.

Results and discussion. Changing the differential heat of adsorption $\left(Q_{\mathrm{d}}\right)$ benzene in the zeolite LiY depending on the amount of adsorption ( $a$-amount of benzene per $1 / 8$ of the unit cell 
$\left(\mathrm{C}_{6} \mathrm{H}_{6} /(1 / 8)\right.$ unit cell $)$ or one supercages $)$ shown in Fig. 1. The dashed line in the figure shows the heat of condensation of benzene $\Delta H_{v}$. The adsorption heats in $\sim 2.3$ times exceed the heat of benzene condensation. Change of the differential heats of adsorption is singular as well.

Heats begin from $108 \mathrm{~kJ} / \mathrm{mol}$ and reduced sharply to $73.5 \mathrm{~kJ} / \mathrm{mol}$ at $0.21 \mathrm{C}_{6} \mathrm{H}_{6} /(1 / 8)$ unit cell, then double pass through a maximum, more pronounced in the range of adsorption, $a, 21-0.49 \mathrm{C}_{6} \mathrm{H}_{6} /(1 / 8)$ unit cell and less pronounced 0,49-0,78 $\mathrm{C}_{6} \mathrm{H}_{6} /$ $(1 / 8)$ unit cell. Further the heat are reduced wavy to $75.21 \mathrm{~kJ} / \mathrm{mol}$ at $\sim 2 \mathrm{C}_{6} \mathrm{H}_{6} /(1 / 8)$ unit cell, then grow to a maximum of $82.28 \mathrm{~kJ} / \mathrm{mol}$ at $4 \sim \mathrm{C}_{6} \mathrm{H}_{6} /$ $(1 / 8)$ unit cell.

Entering into the cavity of the third and fourth molecules leads to an increase of the heat of adsorption due to the contribution to the total energy, the energy of interaction between adsorbate-adsorbate. Location four $\mathrm{C}_{6} \mathrm{H}_{6} / \mathrm{Li}^{+}$complexes is close to the tetrahedral and a cluster fills almost all the space supercages. The fifth entry of the molecule leads to a wavelike decrease of heat at first insignificant, then sharply in the range of 4.36-4.85 $\mathrm{C}_{6} \mathrm{H}_{6} /(1 / 8)$ unit cell.

In accordance with the wavelike $\mathrm{Qd}$ it can be divided into the following sections: $0,78-1,41$; $1,41-1,92 ; 1,92-2,44 ; 2,44-3,08,3,08-3,73,3,73-$ 4,36 and $4,36-5,00 \mathrm{C}_{6} \mathrm{H}_{6} /(1 / 8)$ unit cell, which complete curve and small segment in the range of $5,00-5,18 \mathrm{C}_{6} \mathrm{H}_{6} /(1 / 8)$ unit cell.Total LiY zeolite adsorbs 5.18 of benzene molecules per $1 / 8$ unit cell or one supercages.

On $1 / 8$ unit cell investigated by us the zeolite there is an average of 6.87 cations of $\mathrm{Li}^{+}$. All of them, in accordance with $[7 ; 8 ; 9]$, should be distributed HN on sodalite (SI position ', adjacent to the hexagonal ring that separates the sodalite cavity from the hexagonal prism) and supercages (SII position adjacent to the undivided surface of sodalite cavity). If the position SII, whose number is 4 , fully settled by cations, the remaining 2.87 cations are distributed on positions SI ', whose number is also 4.
So far sodalite cavity with diameter of the input six -membered oxygen window $\sim 0.25 \mathrm{~nm}$ have not been available for a relatively large molecule of benzene. Therefore, we exclude from consideration of adsorption centers in these cavities. Consequently, adsorption mainly proceeds in Supercages. Highenergy area (up to $a=0.21 \mathrm{C}_{6} \mathrm{H}_{6} /(1 / 8)$ unit cell) refers to adsorption on the cations of $\mathrm{Li}^{+}$, are in supercagess in SIII position : These open positions are more accessible to the adsorbed molecules and therefore have the greatest energy of a specific interaction, reaching to $110 \mathrm{~kJ} / \mathrm{mol}$.

The ability of the adsorbed molecules in supercages to extract small size of the cations of $\mathrm{Li}^{+}$from sodalite cells, was shown by us in the adsorption of polar $\mathrm{H}_{2} \mathrm{O}$ and quadrupole $\mathrm{CO}_{2}$ molecules [10]. Two sections $0,21-0,49$ and $0,49-0,78 \mathrm{C}_{6} \mathrm{H}_{6} /(1 / 8)$ unit cell at $\sim 77 \mathrm{~kJ} / \mathrm{mol}$, we refer to benzene adsorption on the lithium cations are in the 4-membered oxygen rings (SIII).

A cation of $\mathrm{Li}^{+}$, located in SII positions due to the small size is immersed in the 6-membered oxygen ring. Therefore, the benzene molecule adsorbed on the cation of lithium in the SII position, cannot be focused more favorably as cation and a negatively charged oxygen atoms forming 6-membered oxygen ring. After the adsorption of benzene on the $\mathrm{Li}^{+}$in the SIII ' position has begun its adsorption on the $\mathrm{Li}^{+}$in SIII position. The further mixed adsorption of $\mathrm{C}_{6} \mathrm{H}_{6} 0.63 /(1 / 8)$ unit cell benzene occurs on lithium cations in the positions of the SII and SIII $\left(0,78-1,41 \mathrm{C}_{6} \mathrm{H}_{6} /(1 / 8)\right.$ unit cell $)$.

It is only two sections $1,41-1,921,92-2,44$ and $\mathrm{C}_{6} \mathrm{H}_{6} /(1 / 8)$ unit cell by $0.5 \mathrm{C}_{6} \mathrm{H}_{6} /(1 / 8)$ unit cell are responsible for the benzene adsorption exclusively on SII lithium cations. The rest of the section is per $0.64 \mathrm{C}_{6} \mathrm{H}_{6} /(1 / 8)$ unit cell each reflects adsorption on the SIII and SII. If each of these sections to subtract a portion of responsible for adsorption on SII, $0,50 \mathrm{C}_{6} \mathrm{H}_{6} /(1 / 8)$ unit cell, the residue corresponding to adsorption SIII, equals $0.144 \mathrm{C}_{6} \mathrm{H}_{6} /$ $(1 / 8)$ unit cell. Such sections are 5, therefore, within 
these sections adsorbed $0.72 \mathrm{C}_{6} \mathrm{H}_{6} /(1 / 8)$ unit cell $(5 \times 0.144=0.72)$. And $0.72+0.57=1.29 \mathrm{C}_{6} \mathrm{H}_{6} /$ $(1 / 8)$ unit cell is adsorbed just taking into account SIII on the second and third sections. With reference to adsorption on SII, $2.5 \mathrm{C}_{6} \mathrm{H}_{6} /(1 / 8)$ unit

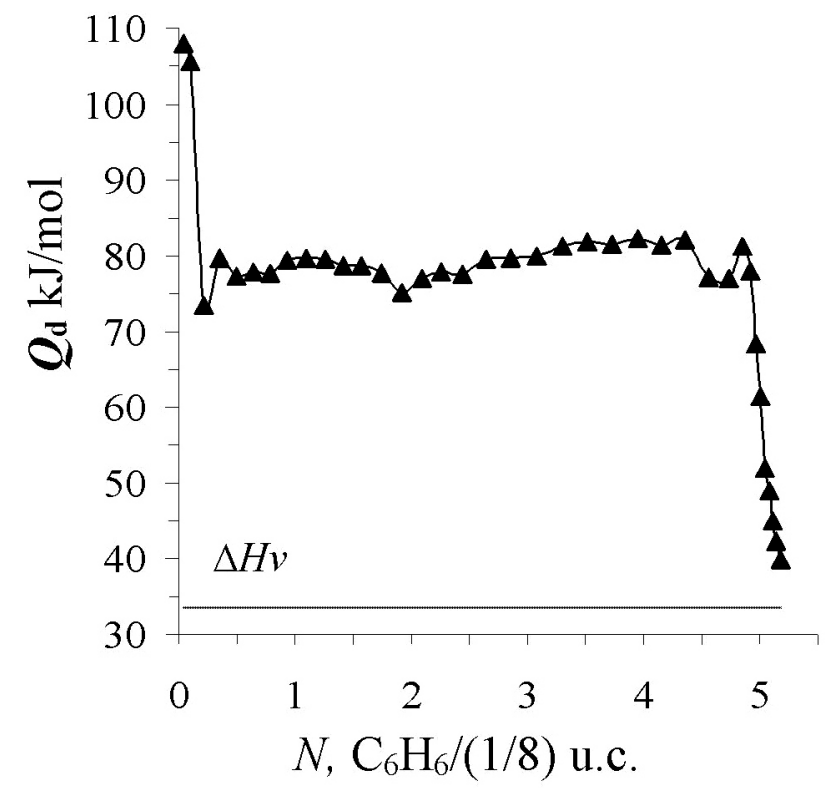

Figure 1. The differential heat of benzene adsorption in the zeolite LiY at 303K. The horizontal dashed line is heat benzene condensation at $303 \mathrm{~K}$

Thus, at saturation of LiY zeolite cavities by $0.21 \mathrm{C}_{6} \mathrm{H}_{6} /(1 / 8)$ unit cell adsorbed on cations in the SIII', 1,29 $\mathrm{C}_{6} \mathrm{H}_{6} /(1 / 8)$ unit cell adsorbed on SIII and 3,5 SII. From 6.87 of lithium cations per 1.8 unit cell in the adsorption process involved 5 . In the last section, after adsorption of $4.36 \mathrm{C}_{6} \mathrm{H}_{6} /(1 / 8)$ unit cell heat begins to decreas from 82.1 to $77.1 \mathrm{~kJ} / \mathrm{mol}$, as is usual at the end of the adsorption process. However, the redistribution of the adsorbed molecules to create more densely packed adsorbate molecules allow to decreased more $0,64 \mathrm{C}_{6} \mathrm{H}_{6} /(1 / 8)$ unit cell, adsorption which leads to a sharp rise of heat of adsorption to the level of $81.3 \mathrm{~kJ} / \mathrm{mol}$. Redistribution of benzene begins after adsorption of $4 \mathrm{C}_{6} \mathrm{H}_{6} /(1 / 8)$ unit cell. In the issue of the redistribution, the fifth molecule of benzene per $1 / 8$ unit cell is displaced to a new the center of $\mathrm{W}$ in the 12 -membered oxygen rings. The small "tail" on the curve $\mathrm{Qd}$ at culminating stage of cell $(5 \times 0.5=2.5)$ are adsorbed in accordance with the five sections in these centers and plus $1 \mathrm{C}_{6} \mathrm{H}_{6} /$ $(1 / 8)$ unit cell $\left(2\right.$ by $0,5 \mathrm{C}_{6} \mathrm{H}_{6} /(1 / 8)$ unit cell of 5 and 6 sections $)$. A total of $3.5 \mathrm{C}_{6} \mathrm{H}_{6} /(1 / 8)$ unit cell adsorbed in the SII.

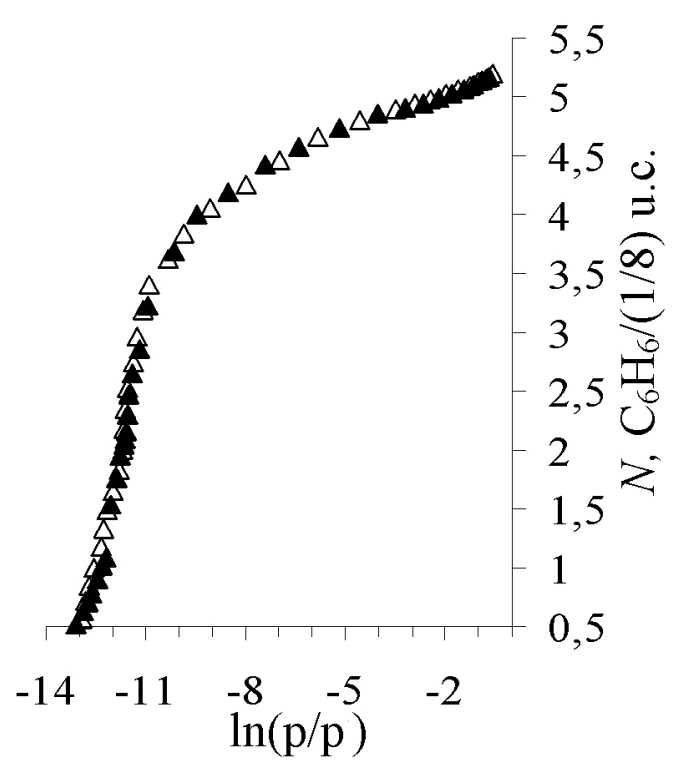

Figure 2. Benzene adsorption isotherm in the zeolite LiY at 303K

$\Delta$ - experimental data $\Delta$ - estimating data by VOM

benzene adsorption ( $a$ from 5 and $5.18 \mathrm{C}_{6} \mathrm{H}_{6} /(1 / 8)$ unit cell with a heat falling from 61 to $40 \mathrm{~kJ} / \mathrm{mole}$ ) is determined by adsorption in mesopores.

The adsorption isotherm was determined by volumetric method at a temperature of $303 \mathrm{~K}$. Control of adsorption equilibrium carefully performed with the thermo-kinetic curves. Figure 2 shows the adsorption isotherm (a) of benzene in the zeolite Li Y. Isotherm was built in semilogarithmic coordinates, allowing you to visually present the adsorption of $a$ in the entire range of equilibrium pressures.

There are identified the adsorption point, the blackout point processed VOM equation in Fig. 2. It is observed that a satisfactory agreement between the experimental and calculated points in the initial and final adsorption areas.

The molar differential entropy of adsorption $(\Delta \mathrm{Sd})$ of benzene in the zeolite LiY calculated by the 
Gibbs-Helmholtz equation of the isotherms and differential heats of adsorption [11-12] and is shown in Figure 3.The initial part of the curve rises from area of the low and negative entropy $\left(-125 \mathrm{~kJ} / \mathrm{mol}^{*}\right.$ $\mathrm{K})$, pointing to a strong localization of benzene adsorbed on $\mathrm{Li}^{+}$cations in the open position of SIII', then passes through a maximum $\left(-30 \mathrm{~kJ} / \mathrm{mol}^{*} \mathrm{~K}\right)$

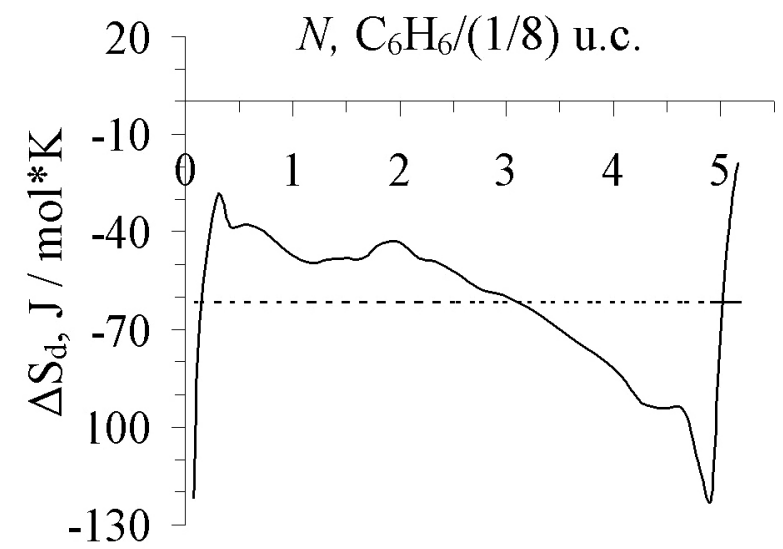

Figure 3. The differential entropy of the benzene adsorption in the zeolite LiY at 303K. Entropy of liquid benzene is taken as zero. The horizontal dashed line - mean molar integral entropy

It is interesting that, when $\mathrm{N}=4,26 \mathrm{C}_{6} \mathrm{H}_{6} /(1 / 8)$ unit cell entropy decrease sharply interrupted and the curve forms a step with a length of $0.4 \mathrm{C}_{6} \mathrm{H}_{6} /(1 / 8)$ unit cell in the range of $4.26-4.66 \mathrm{C}_{6} \mathrm{H}_{6} /(1 / 8)$ unit cell at $92.6 \mathrm{~J} / \mathrm{mol}^{*} \mathrm{~K}$. However, further the entropy decreases sharply up to $123.1 \mathrm{~J} / \mathrm{mol}^{*} \mathrm{~K}$ at $4.9 \mathrm{C}_{6} \mathrm{H}_{6}(/$ $1 / 8)$ unit cell. The adsorption entropy confirms the data heats of adsorption indicating that in this area there is a redistribution of the benzene molecules benzene and formation of densely packed of benzene molecules. The curve sharply rises in the direction of liquid benzene entropy passing through a minimum. Mean molar integral of the entropy of adsorption close to entropy of solid benzene and is equal to -61.4 $\mathrm{J} / \mathrm{mol}^{*} \mathrm{~K}$, which generally indicates the solidlike state of benzene molecules in the zeolite matrix.

After two adsorption of $\mathrm{C}_{6} \mathrm{H}_{6} /(1 / 8)$ unit cell $\tau$ is accelerated and equilibrium is established in av- and at first slowly up to $\mathrm{N}=2 \mathrm{C}_{6} \mathrm{H}_{6} /(1 / 8)$ unit cell, then decreases sharply and at $4.9 \mathrm{C}_{6} \mathrm{H}_{6} /(1 / 8)$ unit cell it becomes two times lower than the solid benzene entropy, is $123 \mathrm{~J} / \mathrm{mol}^{*} \mathrm{~K}$ ), which demonstrates the growing inhibition of translational and rotational motions of benzene molecules with the gradual filling of the adsorption space.

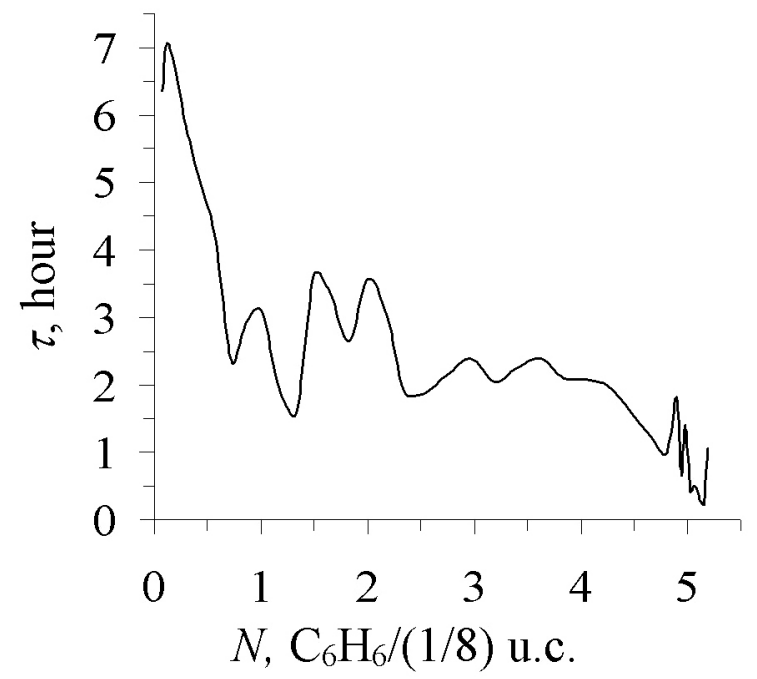

Figure 4. The set-time of the adsorption equilibrium, depending on the size of the adsorption of benzene in the zeolite LiY at 303K

erage for 2-2.5 hours. Accelerate of the adsorption smoothes the waves, but if the rest of the curve divided into sections from the maximum to the maximum, that is got a section with length of $1.0 \mathrm{C}_{6} \mathrm{H}_{6} /$ $(1 / 8)$ unit cell and three at $0.63 \mathrm{C}_{6} \mathrm{H}_{6} /(1 / 8)$ unit cell. The first section corresponds to the adsorption of benzene on the $\mathrm{Li}^{+}$in the SII positions ( 2 by 0.50 $\mathrm{C}_{6} \mathrm{H}_{6} /(1 / 8)$ unit cell $)$ and three sections reflect adsorption on mixed positions of SIII and SII (at 0.63 $\mathrm{C}_{6} \mathrm{H}_{6} /(1 / 8)$ unit cell). Reducing heat in the adsorption is more than $4 \mathrm{C}_{6} \mathrm{H}_{6} /(1 / 8)$ unit cell. It leads to accelerate the process, but benzene redistribution and the appearance of new centers dramatically slows down and the curve $\tau$ passes through maximum at 4.9 and 4.98 unit cell.

The study shows that, along with the isotherm and differential heats of adsorption, entropy and thermo kinetics of adsorption reflects the specifics 
of the formation of the ion / molecular complexes in the zeolite matrix. The mechanism of adsorption, established on the basis of the heats of adsorption and isotherms, fully confirmed. Benzene molecules in the zeolite matrix are strongly localized and their state closes to solidlike. The migration of cations from the sodalite cavities in the supercages flows with a strong slowdown in the adsorption process.

\section{References:}

1. Meier W. M., Olson D. H. // Atlas of Zeolite Structure Types. Butterworth. London.- 1987.

2. Breck D. W. // Zeolite molecular Sieves. Wilunit cell. New York.- 1974.

3. Barrer R.M. // Zeolites and Clay Minerals as Sorbent and Molecular Sieves. Academic Press. London.1978.

4. Klyachko A. L., Brueva T. R., Mishin I. V., Rubinstein A. M. Calorimetric study of the adsorption of bases on zeolites. // Proceedings of the IV National Conference on the adsorbents. L.: Publishing House. "Nauka": Adsorbents, preparation, properties and applications.- 1978.- P. 125-129; Bosachek V., D. Froyde, Kretschmer R. G., and others. There are same.- P. 35-40.

5. Angell C. L., Howell M.V. Infrared spectroscopic investigation of zeolites and adsorbed molecules. J. Phys. Chem // - 1969.- 73 (8).- P. 2551-2554.

6. Coughlan B., Carroll W.M., O' Mallunit P. cell, Nunan J. Benzene in hydrogen zeolites. Infrared spectroscopic and catalytic investigation of variously exchanged hydrogen Y systems. J. Chem. Soc. Faraday Trans. I. // - 1981.- V. 177.- P. 3037-3047.

7. Herden N., Einicke W-D., Schollner R., Mortier W.J., Gellens L. R. and Uytterhoeven B., Location of Li-ions in synthetic zeolite X and Y. / / Zeolites.- 1982.- V. 2.- P. 131-134.

8. Forano C., Slade R. C.T., Krogh Andersen E., Krogh Andersen I. G., and. Prince E. Neutron Diffraction Determination of Full Structures of Anhydrous LiX and LiY Zeolites. J. Solid State Chem / / - 1989.- V. 82.- P 95-102.

9. Herden H. Einicke W-D and Schollner R., Dyer A. Investigations of the arrangement and Mobility of $\mathrm{Li}$ ions in X-and Y-zeolites and the Influence of mono- and Divalent Cations on It.J. Inorg. Nucl. Chem // - 1981.- V. 43.- No. 10.- P. 2533-2536.

10. Rahmatkariev G. U., Rahmatkarieva F. G., Abdurahmonov E. B. Isotherm and differential heat of benzene adsorption in the zeolite LiY / / Uzb. Chem. Journal.- 2013. 1.- P. 13-17.

11. Mentzen B. F., Rakhmatkariev G. U., Host/Guest interactions in zeolitic nonostructured MFI type materials: Complementarity of X-ray Powder Diffraction, NMR spectroscopy, Adsorption calorimetry and Computer Simulations // Узб. хим. журнам.- 2007.- No. 6.- С. 10-31.

12. Rakhmatkariev G. U., Mechanism of Adsorption of Water Vapor by Muscovite: A Model Based on Adsorption Calorimetry // Clays and Clay Minerals,- 2006.- Vol. 54.- P. 423-430. 